\title{
Pengaruh Pembelajaran Kooperatif Tipe Two Stay Two Stray Terhadap Hasil Belajar Al-Qur'an Hadis Ditinjau Dari Self- Efficacy
}

\author{
Muliyani $^{1}$, Ardianto Azis ${ }^{2}$ \\ ${ }^{1}$ Fakultas Agama Islam Universitas Muhammadiyah Kendari \\ Alamat email: muliyani@umkendari.ac.id \\ ${ }^{2}$ Fakultas Agama Islam Universitas Muhammadiyah Kendari \\ Alamat email: ardiantoazis@umkendari.ac.id
}

\begin{abstract}
Abstrak
Artikel ini untuk menguji pengaruh model pembelajaran kooperatif tipe Two Stay Two Stray (TSTS) terhadap hasil belajar hadis ditinjau dari Self-Efficacy siswa kelas XI MIA Madrasah Aliyah Pesantren Ummusshabri Kendari. Penelitian ini merupakan penelitian Quasi Experiment dengan menggunakan posttest design. Data postest ditabulasi dan dianalisis dengan melakukan analisis deskriptif data dan dianalisis secara inferensial. Uji asumsi yang harus dipenuhi dalam analisis statistik parametrik yang diperlukan sebagai dasar dalam pengujian hipotesis. Berdasarkan hasil penelitian dan pembahasan, maka kesimpulan dalam peneleitian ini adalah sebagai berikut. 1) Terdapat pengaruh model pembelajaran kooperatif tipe TSTS terhadap hasil belajar Hadis ditinjau dari Self-efficacy siswa kelas XI MIA Sekolah Madrasah Aliyah Pesantren Ummusabri Kendari. 2) Terdapat pengaruh model pembelajaran kooperatif tipe TSTS terhadap hasil belajar Hadis ditinjau dari Self-efficacy tinggi siswa kelas XI MIA Sekolah Madrasah Aliyah Pesantren Ummusabri Kendari. 3) Terdapat pengaruh model pembelajaran kooperatif tipe TSTS terhadap hasil belajar Hadis ditinjau dari Self-efficacy sedang siswa kelas XI MIA Sekolah Madrasah Aliyah Pesantren Ummusabri Kendari. 4) Terdapat pengaruh model pembelajaran kooperatif tipe TSTS terhadap hasil belajar Hadis ditinjau dari Self-efficacy rendah siswa kelas XI MIA Sekolah Madrasah Aliyah Pesantren Ummusabri Kendari.
\end{abstract}

Kata Kunci: Model TSTS, Hasil Belajar, Self-Efficacy 


\title{
The Effect of Two Stay Two Stray Cooperative Learning on Learning Outcomes of the Al-Qur'an Hadith in terms of Self- efficacy
}

\begin{abstract}
This article is to examine the effect of the Two Stay Two Stray (TSTS) cooperative learning model on the learning outcomes of hadith in terms of the Self-efficacy of class XI MIA students at Madrasah Aliyah Pesantren Ummusshabri Kendari. This research is a Quasi Experiment study using a posttest design. The postest data was tabulated and analyzed by doing descriptive analysis of the data and analyzed inferentially. Test assumptions that must be met in parametric statistical analysis are needed as a basis for hypothesis testing. Based on the results of research and discussion, the conclusions in this study are as follows. 1) There is an effect of the TSTS cooperative learning model on the learning outcomes of Hadith in terms of the Self-efficacy of class XI MIA students at Madrasah Aliyah Islamic Boarding School, Ummusabri Kendari. 2) There is an influence of the TSTS type cooperative learning model on the learning outcomes of Hadith in terms of high self-efficacy of class XI MIA students at Madrasah Aliyah Islamic Boarding School, Ummusabri Kendari. 3) There is an influence of the TSTS type cooperative learning model on the learning outcomes of Hadith in terms of Selfefficacy while the students of class XI MIA Madrasah Aliyah Islamic Boarding School Ummusabri Kendari. 4) There is an effect of the TSTS cooperative learning model on the learning outcomes of Hadith in terms of low self-efficacy of class XI MIA students at Madrasah Aliyah Islamic Boarding School, Ummusabri Kendari.
\end{abstract}

\section{Key Words: TSTS Model, Learning Outcomes, Self-Efficacy}




\section{Pendahuluan}

Mata pelajaran al-Qur'an hadis merupakan mata pelajaran wajib bagi peserta didik oleh karena itu pembelajaran al-Qur'an Hadis harus dapat terlaksana dengan baik (Poetri \& Bahruddin, 2019), (Astuti, 2019). Pada Madrasah Aliyah Pesantren Ummusshabri tujuan pembelajaran dari mata pelajaran al-Qur'an Hadis adalah agar siswa dapat menghayati dan mengamalkan ajaran agama yang dianutnya, memahami, menerapkan dan menganalisis pengetahuan faktual, konseptual, prosedural berdasarkan pengetahuannya, serta siswa dapat mengimplementasikannya dalam bentuk pemgembangan diri. Tujuan pembelajaran Qur'an Hadits berdasarkan Peraturan Menteri Agama Republik Indonesia Nomor 000291 Tahun 2013 adalah (1) meningkatkan kecintaan siswa terhadap al-Qur'an dan Hadits; (2) Membekali siswa dengan dalil-dalil yang terdapat dalam alQur'an dan Hadits sebagai pedoman dalam menyikapi dan menghadapi kehidupan; (3) Meningkatkan pemahaman dan pengamalan isi kandungan al-Qur'an dan Hadits yang dilandasi oleh dasar-dasar keilmuan tentang al-Qur'an dan Hadits (Shodiq, 2019).

Untuk mencapai tujuan tersebut maka guru harus mampu mendesain pembelajaran yang bervariatif sehingga peserta didik lebih termotivasi, tertarik untuk belajar serta siswa dapat mengembangkan kemampuan berpikir, kreativitas dan kemampuan berpikir kritisnya. Karena Pembelajaran merupakan serangkaian kegitan yang direncanakan dengan baik untuk memfasilitasi interaksi anatar peserta didik dan sumber belajar agar tujuan pembelajaran dapat tercapai (Dick and Carey, 2009).

Usaha untuk mewujudkan tujuan pembelajaran Qur'an dan Hadis adalah guru melaksanakan pebelajaran di dalam kelas dengan menggunakan berbagai model pembelajaran. Studi empirkal melalui wawancara dengan seorang guru yang mengajar di kelas bahwa proses pembelajaran masih bersifat konseptual dan pembelajaran yang masih bersifat konvensional dengan pendekatan berpusat pada guru (Teacher Center Approach) Siswa hanya diberikan penjelasan terkait materi serta diberikan tugas untuk menghapal ayat ataupun hadis yang terdapat dalam materi pelajaran al-Qur'an Hadis, siswa masih belum mampu menformulasikan sendiri jawabannya, masih menyesuaikan dengan apa yang diterangkan oleh guru. Pembelajaran tersebut menyebabkan nilai mata pelajaran al-Qur'an Hadis siswa rendah. 
Fakta-fakta yang telah dijelaskan tersebut memberi dampak pada pengembangan kemampuan siswa dalam mata pelajaran alQur'an Hadis atau hasil belajar siswa. Sebagaimana menurut Tohirin (Tohirin, 2014), hasil belajar adalah apa yang telah dicapai oleh peserta didik setelah melakukan kegiatan belajar. Menurut Sudjana (Sudjana, 2017), hasil belajar adalah kemampuan-kemampuan yang dimiliki oleh peserta didik setelah menerima pengalaman-pengalaman belajarnya. Kemudian Santrock (Santrock, 2011), hasil belajar adalah apa yang telah pelajari atau keterampilan yang telah dikuasai oleh peserta didik. Jadi, hasil belajar Qur'an Hadis yang menjadi dampak dalam pembelajaran tersebut adalah kemampuan berupa pengetahuan, keterampilan, dan sikap yang dicapai melalui pengalaman belajar.

Sebagai akibat pendekatan yang digunakan tersebut rendahnya hasil belajar al-Qur'an dan Hadis serta pada giklirannya nanti siswa tidak mampu bersikap logis, kreatif, cermat dan bertanggung jawab, responsif dan mudah menyerah dalam menjalani kehidupan seharihari. Pembelajaran yang demiki juga akan berdampak pada kepercayaan diri peserta didik. Bahwa mereka tidak yakin akan potensi yang dimiliki, karena selama pembelajaran tersebut kemapuan atau kapabilitas mereka kurang tereksplor sealam pembelajaran.

Hal ini sejalan dengan pendapat Wade dan Tavris (Wade \& Tavris, 2007) yang mengemukakan bahwa, keberhasilan seseorang dalam menguasai suatu materi disebabkan oleh keyakinan yang dimilikinya, karena keyakinan yang akan menyebabkan orang tersebut akan menjadi kenyataan. Salah satu sumber keyakinan adalah tingkat kepercayaan diri terhadap kemampuan sendiri (self-efficacy). Bandura (Bandura, 1997) menyatakan bahwa self-efficacy adalah keyakinan akan kemampuan diri yang dimiliki individu untuk menentukan dan melaksanakan berbagai tindakan yang diperlukan untuk menghasilkan suatu pencapaian. Self-efficacy memiliki dampak yang penting, bahkan sebagai motivator utama terhadap keberhasilan seseorang. Schunk (Schunk, 2012) mengatakan bahwa Self-Efficacy merupakan persepsi seseorang tentang kapabilitas yang dimiliki untuk menghasilkan tindakan, termasuk harapan terhadap tindakan dan kepercayaan akan kemampuan untuk mengantisipasi hasil dari suatu tindakan. Dengan demikian, self-efficacy Siswa akan lebih mungkin mengerjakan aktivitas yang dia yakini dapat ia lakukan daripada melakukan pekerjaan yang mereka rasa tidak bisa diselesaikan. SelfEfficacy merupakan keyakinan terhadap kemampuan yang dimiliki 
siswa untuk mengikuti pembelajaran dan menyelesaikan tugas-tugas belajar yang dihadapi serta kemampuan untuk mengantisipasi situasi dan hasil dari tindakan tersebut. Selanjutnya Bandura mengatakan bahwa empat sumber utama Self-Efficacy yaitu penguasaan pengalaman langsung (Enactive Mastery Experiences), pengalaman dari orang lain (Vicarious Experiences), bujukan verbal (Verbal Persuasion) dan keadaan fisik emosional (Physiological And Affective States).

Kemampuan memahami mata pelajaran al-Qur'an Hadis dan self-efficacy memiliki keterkaitan. Keduanya berfungsi sebagai alat untuk menilai keberhasilan siswa dalam menyelesaikan permasalahan sehari-hari. Siswa yang mempunyai sikap percaya diri, menganggap mata pelajaran al-Qur'an Hadis sangat penting untuk kehidupan sehari-hari dan membantu Siswa dalam hidup bermasyarakat. Siswa tidak memiliki percaya diri dalam memahami dan mengkomunikasikan al-Qur'an hadis, dapat dikategorikan sebagai siswa yang memiliki Self-Efficacy rendah. Self-efficacy merupakan salah satu faktor penting dalam menentukan prestasi seseorang khususnya dalam menyelesaikan permasalahan yang diberikan.

Upaya yang dapat dilakukan untuk meningkatkan hasul belajar dan Self-Efficacy dalam pembelajaran qur'an dan hadis adalah denga menerapkan model pembelajaran yang sesuai dengan karakteristik siswa dan materi pelajaran. Model pembelajaran merupakan representasi secara konseptual yang menggambarkan pelaksanaan pembelajaran, yang diajdikan panduan bagi guru untuk mencapai tujuan pembelajaran.

Salah satu model pembelajaran yang dilakukan oleh peneliti menggunakan model pembelajaran kooperatif tipe Two Stay Two Stray (TSTS). Tipe TSTS merupakan model pembelajaran kooperatif yang paling paling unik. Pada pembelajarannya, materi dirancang untuk pembelajaran kelompok. Siswa dengan tingkat kemampuan yang heterogen digabungkan dalam satu kelompok. Dalam satu kelompok terdapat empat orang siswa. siswa bekerja sama dan secara kolaboratif mengerjakan tugas-tugas pembelajaran yang diberikan. Setiap anggota kelompok saling membantu dan bertanggung jawab dalam keberhasilan anggotanya. Selesai diskusi, setiap kelompok dua orang anggota kelompok bertamu di kelompok lainnya sedangkan dua teman lainnya tinggal di kelompoknya. 
Hasil peneltiian Qomariyah, Ita (Qomariyah, 2010) menunjukkan bahwa penerapan teknik Two Stay Two Stray cu/kup efektif dibandingkan pembelajaran konvensional dalam keterampilan berargumentasi siswa pada pembelajaran PAI kelas XI SMA Al-Muniroh Ujungpangkah Gresik. Merikiyana (2019) penerapan model pembelajaran two stay two stray memberikan pengaruh dalam meningkatkan hasil belajar siswa pada materi Hari Kiamat di kelas XII SMA Nurul Iman Palembang. Nurhasanah, N. (2019) menunjukkan bahwa dengan metode eksperimen, penerapan metode Two Stay Two Stray (TSTS) dengan metode Number Head Together (NHT) dapat meningkatkan aktivitas belajar siswa. Kumape, S. (2015) menyatakan bahwa pembelajaran TSTS secara nyata berpengaruh signifikan terhadap aktivitas dan hasil belajar siswa tentang IPA di kelas VI SD Inpres Palupi. Fitriyah, N. I. (Fitriyah, 2012) menghasilkan bahwa model pembelajaran kooperatif two stay two stray efektif terhadap aktivitas dan hasil belajar siswa klasifikasi makhluk hidup di MTs Negeri Sulang.

Berbagai hasil penelitian menunjukkan bahwa Model pembelejaran TSTS dapat berpengaruh terhadap hasil belajar dan aktivita siswa. Namun berbagai penelitian tersebut belum ada yang menerapakan model TSTS pada mata pelajaran al-Quran dan Hadis ditinjau dari Self Efficacy siswa. Oleh karena itu artikel ini akan mengkaji masalah tentang (1) Bagaimana deskripsi hasil belajar alQur'an Hadis siswa kelas XI MIA Madrasah Aliyah Pesantren Ummusshabri Kendari? (2) Bagaimana deskripsi Self-Efficacy siswa kelas XI MIA Madrasah Aliyah Pesantren Ummusshabri Kendari? ;;),(3) Apakah ada pengaruh model pembelajaran kooperatif tipe TSTS terhadap hasil belajar al-Qur'an Hadis ditinjau dari Self-Efficacy siswa kelas XI MIA Madrasah Aliyah Pesantren Ummusshabri Kendari?; (4) Apakah ada pengaruh model pembelajaran kooperatif tipe TSTS terhadap hasil belajar al-Qur'an Hadis ditinjau dari selfefficacy tinggi, sedang, dan rendah siswa kelas XI MIA Madrasah Aliyah Pesantren Ummusshabri Kendari?

Sesuai dengan rumusan masalah, maka tujuan penulisan artikel ini adalah adalah untuk mengkaji dan menganalisis (1) Deskripsi nilai mata pelajaran hadis siswa kelas XI MIA Madrasah Aliyah Pesantren Ummusshabri Kendari, (2) Deskripsi Self-Efficacy siswa kelas XI MIA Madrasah Aliyah Pesantren Ummusshabri Kendari, (3) Pengaruh model pembelajaran kooperatif tipe TSTS terhadap nilai mata 
pelajaran hadis ditinjau dari Self-Efficacy siswa kelas XI MIA Madrasah Aliyah Pesantren Ummusshabri Kendari, (4) Pengaruh model pembelajaran kooperatif tipe TSTS terhadap nilai mata kuliah hadis ditinjau dari self-efficacy tinggi, sedang dan rendah siswa kelas XI MIA Madrasah Aliyah Pesantren Ummusshabri Kendari.

\section{Metode}

Penelitian ini merupakan penelitian Quasi Experiment dengan menggunakan posttest design. Desain penelitian ditentukan berdasarkan kategori self-efficacy siswa terhadap mata pelajaran hadist (tinggi, sedang dan rendah) dan pembelajaran kooperatif tipe TSTS. Desain penelitian yang digunakan adalah posttest only design. Pada kelas eksperimen diberi perlakuan model pembelajaran kooperatif tipe TSTS (X),. Sebelum pemberian perlakuan, kelas tersebut diberi angket self-efficacy, kemudian diberi posttest (O). Penelitian ini akan dilaksanakan di kelas XI Sekolah Madrasah Aliyah Pesantren Ummusabri.

Populasi dari penelitian adalah seluruh siswa kelas XI MIA Sekolah Madrasah Aliyah Pesantren Ummusabri Kendari tahun pelajaran 2016/2017 berjumlah 67 siswa .Teknik pengumpulan data menggunakan tes untuk mengukur kemampuan hadist dan non tes. Teknis analisis data yang digunakan dalam penelitian ini adalah teknik analisis deskriptif dan analisis inferensial. Data self-efficacy dianalisis deskriptif untuk dibagi dalam tiga kategori, yaitu kategori tinggi, sedang dan rendah. Kriteria penskoran untuk tingkatan-tingkatan pada Self-Efficacy mahasiswa dapat dilihat pada tabel 1 berikut:

Tabel 1 Kategori Tingkat Self-Efficacy Mahasiswa

\begin{tabular}{|c|c|}
\hline Skor & Kategori \\
\hline Mean $+(0,5 \times \mathrm{sd}) \leq \mathrm{X}$ & Tinggi \\
\hline Mean $-(0,5 \times \mathrm{sd}) \leq \mathrm{X}<$ Mean $+(0,5 \times \mathrm{sd})$ & Sedang \\
\hline $\mathrm{X}<$ Mean $-(0,5 \times \mathrm{sd})$ & Rendah \\
\hline
\end{tabular}

Sumber: Arikunto. S (2009)

Tahap selanjutnya adalah menguji asumsi yang harus dipenuhi dalam analisis statistik parametrik yang diperlukan sebagai dasar dalam pengujian hipotesis. Uji normalitas data dimaksudkan untuk mengetahui apakah data yang diperoleh berasal dari populasi yang 
berdistribusi normal atau tidak berdistribusi normal. Uji normalitas digunakan uji Kolmogorov-Smirnov. Uji homogenitas varians populasi dimaksudkan untuk mengetahui apakah varians dari kedua sampel yang diselidiki homogen atau tidak homogen. Uji homogenitas digunakan Levene Test . Analisis data menggunakan bantuan software IBM Statistics SPSS 21. Kriteria untuk mengambil keputusan adalah: Jika nilai sig $\geq \alpha(0.05)$, maka $\mathrm{H}_{0}$ diterima, yang berarti kedua kelas mempunyai varians homogen. Dan Jika nilai sig $<\alpha(0.05)$, maka $\mathrm{H}_{0}$ ditolak, yang berarti kedua kelas mempunyai varians tidak homogen.

\section{Hasil Penelitian}

\section{Deskripsi Hasil Belajar Al Quran Hadis}

Data hasil belajar Al-Qur'an Hadisdiperoleh melalui tes hasil belajar Al Quran Hadis. Tes hasil belajar Al-Qur'an Hadisdiberikan kepada kelompok eksperimen yang diajar dengan model pembelajaran Two Stay Two Stray (TSTS) setelah perlakuan (postes).

Deskripsi hasil perhitungan selengkapnya dapat dilihat pada Tabel 2 berikut:

Tabel 2. Gambaran Data Postes Kelompok untuk Hasil Belajar Al Quran Hadis

\begin{tabular}{|c|l|l|}
\hline & & postes \\
\hline \multirow{4}{*}{$\begin{array}{c}\text { Kelas TSTS secara } \\
\text { Keseluruhan }\end{array}$} & Mean & 75.55 \\
\cline { 2 - 3 } & Standar deviasi & 10.24 \\
\cline { 2 - 3 } & Nilai maksimum & 60 \\
\cline { 2 - 3 } & Nilai minimum & 90 \\
\hline
\end{tabular}

Berdasarkan Tabel 2, diperoleh bahwa pada kelas eksperimen atau kelas yang diajar dengan model pembelajaran TSTS nilai ratarata postes sebesar 75.55 , standar deviasi 10,24 , nilai siswa terendah 60 dan nilai siswa tertinggi 90.

Berdasarkan Self-Efficacy, siswa dibagi atas 3 kategori yaitu Self-Efficacy tinggi, sedang dan rendah. Secara deskriptif kemampuan hasil belajar Al-Qur'an Hadissiswa berdasarkan kategori Self-Efficacy (SE) siswa dapat dilihat pada Tabel 3 di bawah ini: 
Tabel 3 Hasil analisis Deskriptif Kemampuan Al-Qur'an Hadis ditinjau dari Self-Efficacy siswa

\begin{tabular}{|c|l|l|}
\hline \multirow{4}{*}{ Kategori SE Tinggi } & & $\begin{array}{l}\text { Postes Kemampuan Al } \\
\text { Quran Hadis }\end{array}$ \\
\cline { 2 - 3 } & Mean & 86.12 \\
\cline { 2 - 3 } & Standar deviasi & 6.79 \\
\cline { 2 - 3 } & Nilai maksimum & 70 \\
\cline { 2 - 3 } & Nilai minimum & 90 \\
\hline \multirow{5}{*}{ Kategori SE Sedang } & Mean & 76 \\
\cline { 2 - 3 } & Standar deviasi & 3.27 \\
\cline { 2 - 3 } & Nilai maksimum & 70 \\
\cline { 2 - 3 } & Nilai minimum & 80 \\
\hline & Mean & 64.37 \\
\cline { 2 - 3 } & Standar deviasi & 4.17 \\
\cline { 2 - 3 } & Nilai maksimum & 60 \\
\cline { 2 - 3 } & Nilai minimum & 70 \\
\hline
\end{tabular}

Berdasarkan Tabel 1, diperoleh bahwa pada kelas yang diajar dengan model pembelajaran TSTS dengan SE kategori tinggi nilai rata-rata postes sebesar 82,12, standar deviasi 6,79 , nilai siswa terendah 70 dan nilai siswa tertinggi 90. Pada kelas yang diajar dengan model pembelajaran TSTS dengan SE kategori sedang nilai rata-rata postes sebesar 76, standar deviasi 3, 27 , nilai siswa terendah 70 dan nilai siswa tertinggi 80 . Pada kelas yang diajar dengan model pembelajaran TSTS dengan SE kategori rendah nilai rata-rata postes sebesar 64,37, standar deviasi 4,17, nilai siswa terendah 60 dan nilai siswa tertinggi 70 .

\section{Hasil Analisis Inferensial Data Hasil Belajar Al Quran Hadis}

Analisis inferensial yang dilakukan diawali dengan beberapa uji prasyarat untuk postes, di antaranya uji normalitas dan uji homogenitas varians. Uji normalitas dilakukan untuk mengetahui apakah data bersistribusi normal atau tidak sedangkan uji homogenitas varians dilakukan untuk mengetahui kehomogenan varians dari populasi.

Pengujian normalitas data dilakukan terhadap data hasil belajar Al-Qur'an Hadispada kelas yang diajar TSTS. Uji tersebut dilakukan 
dengan uji Kolmogorov-Sminorv dengan taraf signifikansi 0,05. Kriteria pengujian yang digunakan adalah: jika nilai probabilitas ( $s i g$.) dari Z lebih besar dari $\alpha=0,05$, maka H0 diterima; dalam hal lainnya, HO ditolak. Hasil perhitungan uji normalitas pada kelas yang diajar dengan TSTS selengkapnya disajikan pada tabel 4.

\section{Tabel 4. Uji Normalitas Distribusi Data Kelas yang diajar dengan TSTS Secara Keseluruhan Maupun Ditinjau dari Kategori Self- Efficacy}

\begin{tabular}{|l|l|l|l|}
\hline & Nilai Sig. & Keputusan & Kesimpulan \\
\hline $\begin{array}{l}\text { Secara keseluruhan } \\
\text { (tanpa pengkategorian SE) }\end{array}$ & 0.873 & $\begin{array}{l}\text { H0 } \\
\text { diterima }\end{array}$ & Normal \\
\hline Ketegori SE tinggi & 0.429 & $\begin{array}{l}\text { H0 } \\
\text { diterima }\end{array}$ & Normal \\
\hline Kategori SE sedang & 0,687 & $\begin{array}{l}\text { H0 } \\
\text { diterima }\end{array}$ & Normal \\
\hline Kategori SE rendah & 0,801 & $\begin{array}{l}\text { H0 } \\
\text { diterima }\end{array}$ & Normal \\
\hline
\end{tabular}

Berdasarkan hasil output uji normalitas data dengan menggunakan uji Kolmogorov-Sminorv pada Tabel 2, nilai signifikansi untuk kemampuan Al-Qur'an Hadissecara keseluruhan (tanpa pengkategorian SE) adalah 0,873 lebih besar dari $\alpha=0,05$, Kategori SE tinggi adalah 0,429 lebih besar dari $\alpha=0.05$, Kategori SE sedang adalah 0,687 lebih besar dari $\alpha=0.05$, dan Kategori SE rendah adalah 0,801 lebih besar dari $\alpha=0.05$, Kerena nilai signifikansi keempat kelompok lebih besar dari 0,05, maka ini menunjukan bahwa data mempunyai sebaran data yang mengikuti populasi berdistribusi normal.

Selanjutnya pengujian homogenitas data dilakukan terhadap data hasil belajar Al-Qur'an Hadispada kelas eksperimen. Uji tersebut bertujuan untuk mengetahui homogenitas varians data. Pengujian homogenitas data dilakukan dengan uji Levene dengan taraf signifikansi 0,05.

Hasil perhitungan uji homogenitas varians pada postes kelas eksperimen dalam hal ini kelas yang mendapatkan perlakuan dengan 
pembelajaran TSTS selengkapnya disajikan pada Lampiran. Hasil perhitungan uji homogenitas varians dapat disajikan pada Tabel 5.

Tabel 5. Uji Homogenitas Varians Data Kelas yang Diajar dengan TSTS

\begin{tabular}{|c|c|c|c|}
\hline \multicolumn{4}{|c|}{ Test of Homogeneity of Variances } \\
\hline \multicolumn{2}{|c|}{} & & \\
\hline Levene Statistic & df1 & df2 & Sig. \\
\hline 0.770 & 2 & 21 & .476 \\
\hline
\end{tabular}

Berdasarkan hasil output uji homogenitas varians dengan menggunakan uji Levene pada Tabel 3, nilai signifikansinya adalah 0,476. Karena nilai signifikansinya lebih besar dari 0,05 , maka dapat disimpulkan bahwa data postes hasil belajar Al-Qur'an Hadispada kelompok SE memiliki varians data yang sama, atau ketiga data homogen.

Hasil pengujian hiptesis peneltian yang terdiri dari tiga hipoteisis dapat diuraikan berikut. Hipotesis 1 berbunyi "Secara signifikan terdapat pengaruh model pembelajaran kooperatif tipe TSTS terhadap nilai mata pelajaran Hadis ditinjau dari Self-efficacy siswa kelas XI MIA Sekolah Madrasah Aliyah Pesantren Ummusabri Kendari”. Hasil pengujian hipotesis ini dapat dilihat pada Tabel 6 di bawah ini:

\section{Tabel 6. Hasil Analisis Hipotesis 1}

\section{ANOVA}

Nilai

\begin{tabular}{|l|r|r|r|r|r|}
\hline & \multicolumn{1}{|c|}{$\begin{array}{c}\text { Sum of } \\
\text { Squares }\end{array}$} & df & Mean Square & \multicolumn{1}{c|}{ F } & Sig. \\
\hline Between Groups & 1895.250 & 2 & 947.625 & 38.510 & .000 \\
Within Groups & 516.750 & 21 & 24.607 & & \\
Total & 2412.000 & 23 & & & \\
\hline
\end{tabular}

Berdasarkan hasil analisis di atas diperoleh bahwa $\mathrm{F}$ hitung $=$ 38,510 atau nilai sig. 0.000 lebih kecil dari $\alpha=0.05$ maka H0 ditolak. Hal ini dapat disimpulkan bahwa terdapat pengaruh model 
pembelajaran kooperatif tipe TSTS terhadap nilai mata pelajaran Hadis ditinjau dari Self-efficacy siswa kelas XI MIA Sekolah Madrasah Aliyah Pesantren Ummusabri Kendari.

Hipotesis 2 berbunyi "Secara signifikan terdapat pengaruh model pembelajaran kooperatif tipe TSTS terhadap nilai mata pelajaran Hadis ditinjau dari Self-efficacy tinggi siswa kelas XI MIA Sekolah Madrasah Aliyah Pesantren Ummusabri Kendari”. Pengujian hipotesis ini dapat dilihat pada Tabel 5 di bawah ini:

\section{Tabel 7. Hasil Analisis hipotesis 2}

\begin{tabular}{|l|l|l|l|l|}
\hline & T & Df & Sig. & Keterangan \\
\hline SE Tinggi & 6.715 & 7 & 0.000 & H0 ditolak \\
\hline
\end{tabular}

Berdasarkan hasil analisis di atas diperoleh bahwa t hitung = 6.715 atau nilai sig. 0.000 lebih kecil dari $\alpha=0.05$ maka H0 ditolak. Hal ini dapat disimpulkan bahwa terdapat pengaruh model pembelajaran kooperatif tipe TSTS terhadap nilai mata pelajaran Hadis ditinjau dari Self-efficacy tinggi siswa kelas XI MIA Sekolah Madrasah Aliyah Pesantren Ummusabri Kendari.

Hipotesis 3 berbunyi "Secara signifikan terdapat pengaruh model pembelajaran kooperatif tipe TSTS terhadap nilai mata pelajaran Hadis ditinjau dari Self-efficacy sedang siswa kelas XI MIA Sekolah Madrasah Aliyah Pesantren Ummusabri Kendari”. Pengujian hipotesis ini dapat dilihat pada Tabel 6 di bawah ini:

Tabel 8 Hasil Analisis hipotesis 3

\begin{tabular}{|l|l|l|l|l|}
\hline & T & Df & Sig. & Keterangan \\
\hline $\begin{array}{l}\text { SE } \\
\text { Sedang }\end{array}$ & 5.292 & 7 & 0.001 & H0 ditolak \\
\hline
\end{tabular}

Berdasarkan hasil analisis di atas diperoleh bahwa t hitung = 5.292 atau nilai sig. 0.001 lebih kecil dari $\alpha=0.05$ maka H0 ditolak. Hal ini dapat disimpulkan bahwa terdapat pengaruh model pembelajaran kooperatif tipe TSTS terhadap nilai mata pelajaran Hadis ditinjau dari Self-efficacy sedang siswa kelas XI MIA Sekolah Madrasah Aliyah Pesantren Ummusabri Kendari. 
Hipotesis 4 berbunyi "Secara signifikan terdapat pengaruh model pembelajaran kooperatif tipe TSTS terhadap nilai mata pelajaran Hadis ditinjau dari Self-efficacy rendah siswa kelas XI MIA Sekolah Madrasah Aliyah Pesantren Ummusabri Kendari”. Pengujian hipotesis ini dapat dilihat pada Tabel 9 di bawah ini:

Tabel 9 Hasil Analisis Hipotesis 4

\begin{tabular}{|l|l|l|l|l|}
\hline & T & Df & Sig. & Keterangan \\
\hline $\begin{array}{l}\text { SE } \\
\text { Rendah }\end{array}$ & $-3,813$ & 7 & 0.007 & H0 ditolak \\
\hline
\end{tabular}

Berdasarkan hasil analisis di atas diperoleh bahwa t hitung = 3,813 atau nilai sig. 0.007 lebih kecil dari $\alpha=0.05$ maka H0 ditolak. Hal ini dapat disimpulkan bahwa terdapat pengaruh model pembelajaran kooperatif tipe TSTS terhadap nilai mata pelajaran alQur'an Hadis ditinjau dari Self-efficacy rendah siswa kelas XI MIA Sekolah Madrasah Aliyah Pesantren Ummusabri Kendari.

\section{Pembahasan}

\section{Model TSTS dan Aktifitas Belajar Siswa}

Hasil analisis data secara inferensial menunjukkan bahwa terdapat pengaruh model pembelajaran TSTS terhadap peningkatan hasil belajar Al Quran Hadis. Hal ini disebabkan karena selema pembelajaran Al-Qur'an Hadis melalui model TSTS siswa senang dan aktif selama proses pembelajaran. Kemudian siswa sangat antusias karena model tersebut dianggab baru oleh siswa. Di samping itu pengaruh tersebut karena kelebihan yang dmiliki oleh model TSTS, yaitu (1) dapat diterapkan pada semua kelas/tingkatan, (2) kecenderungan belajar siswa menjadi lebih bermakna, (3) lebih berorientasi pada keaktifan, (4) diharapkan siswa akan berani mengungkapkan pendapatnya, (5) menambah kekompakan dan rasa percaya diri siswa, (6) kemampuan berbicara siswa dapat ditingkatkan, dan (7) membantu meningkatkan minat dan prestasi belajar.

Aktivitas siswa dalam pembelajaran dengan model pembelajaran TSTS berlangsung secara optimal mulai dari aktivitas dalam kelompok untuk menyelesaikan masalah yang telah disajikan dalam Lembar Kerja Siswa (LKS), maupun aktivitas dalam kelas 
untuk berinteraksi terhadap kelompok lain melalui diskusi kelas. Secara umum, dalam pembelajaran ini siswa diedukasi untuk membentuk pengetahuannya sendiri melalui rangkaian penyelesaian masalah yang dirumuskan pada LKS.

Sifat dari LKS itu mampu untuk mendorong siswa untuk melakukan reinvention terhadap pemahaman siswa dimasa lalu, Ini tampak ketika siswa terlihat sedang mengingat-ingat kembali materi yang telah diperoleh sebelumnya serta melakukan diskusi terhadap teman dalam kelompoknya. Hal itu sangat lazim terjadi dalam AlQur'an Hadis secara utuh, sebab konsep Al-Qur'an Hadis bersifat hirarkis dan saling terkait. Oleh karena itu, untuk mempelajari AlQur'an Hadis haruslah secara kontinyu dan tidak terputus-putus, belajar Al-Qur'an Hadisdengan terputus-putus akan mengganggu terjadinya proses pembelajaran.

Aktivitas siswa dalam proses pembelajaran dengan TSTS memungkinkan hasil belajar Al-Qur'an Hadis meningkat. Hasil observasi selama eksperimen menunjukkan bahwa aktivitas siswa setiap pembelajaran cenderung meningkat, hingga pada akhir pertemuan pada kelas TSTS ini beberapa aktivitas siswa yang berkaitan dengan hasil belajar Al-Qur'an Hadissiswa mencapai kategori sangat aktif.

Hasil tersebut sejalan dengan apa yang ditemukan oleh Qomariyah, Ita (Qomariyah, 2010); (Merikiyana, 2019); Nurhasanah, N. (Nurhasanah, 2019); (Kumape, 2015); (Fitriyah, 2012) bahwa Model Kooperatif tipe TSTS berpengaruh ppositif terhadap aktivitas belajar dan hasil belajar, kemampuan beragrgumentasi dalam pembelajaran Pendidikan Agama Islam (PAI) dan Ilmu Pengetahuan Alam (IPA).

Keaktifan siswa dalam kelompok didukung dengan kemampuan Self-Efficacy siswa. Pengelompokkan dilakukan secara heterogen artinya setiap kelompok terdapat siswa yang mempunyai Self-Efficacy siswa kategori tinggi, sedang dan rendah. Tujuan peneliti dilakukan pengelompokkan seperti ini agar siswa yang mempunyai Self-Efficacy rendah dapat dibantu oleh siswa yang mempunyai Self-Efficacy sedang dan tinggi. Peneliti menemukan di lapangan bahwa siswa yang mempunyai Self-Efficacy rendah masih malu-malu dalam mengemukakan ide yang dimiliki dalam proses pembelajaran. 
Hal ini didukung oleh Bandura (Bandura, 1995: 14) bahwa self-efficacy akan mempengaruhi tindakan, upaya, ketekunan, fleksibilitas dalam perbedaan, dan realisasi dari tujuan dari individu ini, sehingga self-efficacy yang terkait dengan kemampuan seseorang seringkali menentukan outcome sebelum tindakan terjadi. Hal senada yang dikemukakan oleh Kostagiolas, Lafronas, dan Korfiatis, (2019:6) yang menyatakan bahwa kepuasan diri dan Self-Efficacy merupakan hal sangat esensial untuk memperbaiki kinerja akademik peserta didik. Huang, Lee dan Yang (2019:57) menemukan bahwa Self-Efficacy guru dapat mendorong sikap kreatifitas siswa dan sikap positif dalam pembelajaran.

Self-efficacy siswa mampu mendorong siswa untk percaya diri dalam menyelesaikan tugas-tugas dan ujian pada Qur'an Hadis siswa. Karena Self-efficacy merupakan kontruksi sentral dalam teori kognitif sosial yang dimiliki seseorang akan mempengaruhi pengambilan keputusannya dan mempengaruhi tindakan yang akan dilakukannya, seseorang akan cenderung menjalankan sesuatu apabila ia merasa kompeten dan percaya diri, dan menghindarinya apabila tidak;

Kemudian dengan self efficacy yang dmiliki oleh siswa maka membantu seberapa jauh upaya ia bertindak dalam suatu aktivitas, berapa lama ia bertahan apabila mendapat masalah dan seberapa fleksibel dalam suatu situasi yang kurang menguntungkan baginya, dalam hal ini semakin besar self-efficacy seseorang maka semakin besar upaya ketekunan dan fleksibilitasnya.

Selanjutnya dengan self-efficacy maka akan mempengaruhi pola pikir dan reaksi emosionalnya. Siswa dengan self-efficacy yang rendah mudah menyerah dalam menghadapi masalah, cenderung menjadi stress, depresi dan mempunyai suatu visi yang sempit tentang apa yang terbaik untuk menyelesaikan masalah itu. Sedangkan selfefficacy yang tinggi akan membantu seseorang dalam menciptakan suatu perasaan tenang dalam menghadapi masalah atau aktivitas yang sukar. Moris (Moris, 2013:27) mengatakan bahwa Self-Efficacy Beliefes menemukan bahwa kondisi emosional dan pola pikir dapat mempengaruhi Self-Efficacy.

Proses pembelajaran dengan TSTS juga sangat berdampak posistif terhadap kemampuan hasil belajar Al-Qur'an Hadis siswa. Hal yang paling unik di dalam pelaksanaan di kelas yaitu siswa diberi tugas untuk bertamu dan menerima tamu. Tujuan dari siswa yang bertamu adalah untuk mencari informasi atau menyamakan hasil kerja 
kelompok, sedangkan tujuan dari siswa penerima tamu adalah untuk menyampaikan informasi kepada siswa yang bertamu terkait dengan hasil jawaban yang telah diselesaikan di dalam kelompoknya. Oleh sebab itu, model pembelajaran kooperatif tipe TSTS dan Self-Efficacy mempunyai pengaruh terhadap hasil belajar Al-Qur'an Hadis siswa.

\section{Self-Efficacy dalam Perspektif yang Lebih Luas}

Self-Efficacy memiliki pengaruh yang sangat penting terhadap kinerja individual (Engko, 2008), (Indrawati, 2014). Kepercayaan diri bertumpu proses individual yang panjang, melalui proses latihan secara berkelanjutan. Seorang individu yang memiliki kepercayaan diri yang tinggi lebih berpeluang untuk menghasilkan kinerja yang tinggi. Efek lain yang diperoleh adalah kemantafan dalam pengambilan keputusan (Widyastuti, 2013), termasuk ketika seseorang memasuki dunia usaha yang membutuhkan kemandirian (Marini \& Hamidah, 2014).

Oleh karena itu Self-efficacy tidaklah diperoleh secara tibatiba, melainkan proses mengalami sesuatu secara berulang-ulang sehingga menimbulkan keyakinan dengan kemampuan untuk melakukan sesuatu. Faktor orang sekitar dapat juga menjadi perangsang tumbuhnya efficacy, ketika seseorang yakin bahwa apa yang dapat dikerjakan orang lain maka dapat pula ia kerjakan. Dapat dikatakan bahwa Self-efficacy memiliki hubungan yang kuat dengan motivasi (Noviawati, 2016). Pengalaman yang panjang akan menghasilkan kematangan pada seseorang (Pinasti, 2011).

Temuan-temuan di atas menunjukkan bahwa self-efficacy sangat dibutuhkan oleh semua orang, penting dibangun sejak dini pada siswa-siswa di sekolah sehingga menjadi modal ketika memasuki dunia kerja dan hidup bermasyarakat. Peran-peran penting yang ditunjukkan seseorang ketika memasuki dunia kerja dan masyarakat luas tentu akan ditopang oleh self-efficacy yang tinggi.

\section{Kesimpulan dan Implikasi}

Berdasarkan hasil penelitian dan pembahasan, maka kesimpulan dalam peneleitian ini adalah sebagai berikut (1) Terdapat pengaruh model pembelajaran kooperatif tipe TSTS terhadap nilai mata pelajaran Hadis ditinjau dari Self-efficacy siswa kelas XI MIA Sekolah Madrasah Aliyah Pesantren Ummusabri Kendari, (2) Terdapat pengaruh model pembelajaran kooperatif tipe TSTS terhadap 
nilai mata pelajaran Hadis ditinjau dari Self-efficacy tinggi siswa kelas XI MIA Sekolah Madrasah Aliyah Pesantren Ummusabri Kendari, (3) Terdapat pengaruh model pembelajaran kooperatif tipe TSTS terhadap nilai mata pelajaran Hadis ditinjau dari Self-efficacy sedang siswa kelas XI MIA Sekolah Madrasah Aliyah Pesantren Ummusabri Kendari, (4) Terdapat pengaruh model pembelajaran kooperatif tipe TSTS terhadap nilai mata pelajaran Hadis ditinjau dari Self-efficacy rendah siswa kelas XI MIA Sekolah Madrasah Aliyah Pesantren Ummusabri Kendari

Berdasarkan kesimpulan di atas, Rendahnya hasil belajar dan kurangnya partisipasi siswa dalam pembelajaran salah satunya dipengaruhi Self-Efficacy dan model pembelajaran yang diterapkan oleh guru. Peneliti menyarankan untuk menggunakan salah satu alternatif model pembelajaran yaitu model pembelajaran TSTS dengan mengkategorikan Self-Efficacy terlebih dahulu. 


\section{Daftar Pustaka}

Arikunto, S. (2009). Prosedur Penelitian Suatu Pendekatan Praktek Edisi Revisi V. Jakarta: Rineka Cipta.

Astuti, S. A. (2019). PENGEMBANGAN MEDIA PEMBELAJARAN MELALUI PROGRAM PREZI PADA MATA PELAJARAN AL QUR'AN HADIS DI MADRASAH ALIYAH. Al-Tarbawi Al-Haditsah: Jurnal Pendidikan Islam, 4(1).

Bandura, A. 1997. Self-Efficacy: The Exercise of Control. New York: W. H. Freedman and Company.

Burhanuddin, N. (2016). Akar Dan Motif Fundamentalisme Islam:Reformulasi Tipologi Fundamentalisme Dan

Prospeknya Di Indonesia. Wawasan: Jurnal Ilmiah Agama Dan Sosial Budaya, Vol. 1, No. 2 , 100-118.

Departemen Agama RI (2013). Peraturan Menteri Agama Republik Indonesia Nomor 000291 Tahun 2013 Tentang Kurikulum Madrasah 2013 Mata Pelajaran Pendidikan Agama Islam dan Bahasa Arab .

Dick, W., Carey, L., \& Carey, J. O. (2015). The Systematic Design of Instrucisional. Boston: Pearson.

Engko, C. (2008). Pengaruh kepuasan kerja terhadap kinerja individual dengan self esteem dan self efficacy sebagai variabel intervening. Jurnal bisnis dan akuntansi, 10(1), 1-12.

Fitriyah, N. I. (2012). Efektivitas Kooperatif Two Stay-Two Stray Terhadap Aktivitas dan Hasil Belajar Siswa. Journal of Biology Education, 1(2).

Huang, Xianhan., Lee, John Chi-Kin,. dan Xiaoping Yang, (2019). "What Really Counts? Investigating the Effects of Creative Role Identity and Self-efficacy on Teachers' Attitudes Towards the Implementation of Teaching for Creativity,". Teaching and Teacher Education, 84 (2019), h. 57. https://doi.org/10.1016/j.tate.2019.04.017 (Diakses 8 Agusutus 2019)

Indrawati, Y. (2014). Pengaruh Self Esteem, Self Efficacy Dan Kepuasan Kerja Terhadap Kinerja Karyawan (Studi Kasus Perawat RS Siloam Manado). Jurnal Riset Bisnis dan Manajemen, 2(4). 
Juli Widyastuti, R. (2013). Pengaruh self efficacy dan dukungan sosial keluarga terhadap kemantapan pengambilan keputusan karir siswa. Jurnal BK Unesa, 3(1).

Kumape, S. (2015). Pengaruh penerapan model pembelajaran kooperatif tipe two stay two stray terhadap aktivitas dan hasil belajar siswa tentang IPA di Kelas VI SD Inpres Palupi. Jurnal Kreatif Online, 4(4).

Marini, C. K., \& Hamidah, S. (2014). Pengaruh self-efficacy, lingkungan keluarga, dan lingkungan sekolah terhadap minat berwirausaha siswa SMK jasa boga. Jurnal Pendidikan Vokasi, 4(2).

Merikayana, R. (2019). Penerapan Model Pembelajaran Cooperative Learning Tipe Two Stay Two Stray Dalam Meningkatkan Hasil Belajar Siswa Mata Pelajaran Pai Pada Materi Hari Kiamat Di Kelas Xii Sekolah Menengah Atas (SMA) Nurul Iman Palembang (Doctoral dissertation, UIN Raden Fatah Palembang).

Morris,. (2013). The Sources and Maintenance of Professional Golfers ' Self-Effiacy Beliefs'. Jurnal The Sport Psychologist ,130-142. Nurhasanah, N. (2019). Penerapan metode Two Stay Two Stray (TSTS) dengan metode Number Head Together (NHT) dalam meningkatkan aktivitas belajar siswa: Penelitian quasi eksperimen siswa kelas VII E dan VII F pada pembelajaran PAI di SMPN 56 Bandung Kecamatan Panyileukan Kota Bandung (Doctoral dissertation, UIN Sunan Gunung Djati Bandung).

Kostagiolas, Petros., Lavranos, Charilaos., dan Korfiatis, Nikolaos. (2019). Learning Analytics: Survey Data for Measuring the Impact of Study Satisfaction on Students' Academic SelfEfficacy and performance,"Data in Brief, 25 ( 2019): h. 6. https://doi.org/10.1016/j.dib.2019.104051.

RIZKI NOVIAWATI, D. I. A. N. (2016). Pengaruh self efficacy terhadap kinerja karyawan dengan motivasi sebagai variabel intervening (studi pada karyawan divisi finance dan human resources pt. coca-cola distribution indonesia, surabaya). Jurnal Ilmu Manajemen (JIM), 4(3).

Poetri, M., \& Bahruddin, E. (2019). Hubungan Kemampuan Baca Tulis Al-Qur'an terhadap Prestasi Belajar Siswa pada Mata 
Pelajaran Al-Qur'an Hadist di MTS Al-Muasyarah Bogor. eJurnal Mitra Pendidikan, 3(5), 686-697.

Qomariyah, I. (2010). Studi Komparasi Tentang Pembelajaran Kooperatif Teknik Two Stay Two Stray Dengan Pembelajaran Konvensional Dalam Keterampilan Berargumentasi Siswa Pada Pembelajaran Pai Di Sma Al-Muniroh Ujungpangkah Gresik (Doctoral dissertation, UIN Sunan Ampel Surabaya).

RIZKI NOVIAWATI, D. I. A. N. (2016). Pengaruh self efficacy terhadap kinerja karyawan dengan motivasi sebagai variabel intervening (studi pada karyawan divisi finance dan human resources pt. coca-cola distribution indonesia, surabaya). Jurnal Ilmu Manajemen (JIM), 4(3).

Schunk, Dale S. (2012). Learning Theories, an Educational Perspective. Boston: Pearson.

Shodiq, S. F. (2019). Revival Tujuan Pembelajaran Pendidikan Agama Islam (PAI) di Era Revolusi Industri 4.0. At-Tajdid: Jurnal Pendidikan dan Pemikiran Islam, 2(02).

Sudjana, Nana. (2017). Penilaian Hasil Proses Belajar Mengajar, (Cet. XXI; Bandung: Remaja Rosdakarya, 22.

Santrock, John W. (2011). Educational Psychology. New York: Mc Graw Hill Edactional, 436.

Tohirin. (2014). Psikologi Pembelajaran Pendidikan Agama Islam (Berbasis Integrasi dan Kompetensi. Jakarta: Raja Grafindo Persada, 151.

Wade, C dan Tavris, C. 2007. Psikologi. Jakarta: Erlangga, 34. 